Bull. Mater. Sci., Volume 3, Number 3, November 1981, pp. 375-379. Printed in India.

\title{
Elemental characterisation of aluminium used in reactors by optical emission spectroscopic methods
}

\author{
L C CHANDOLA \\ Spectroscopy Division, Bhabha Atomic Research Centre, Trombay, \\ Bombay 400085 india
}

MS received 23 March 1981

\begin{abstract}
Using AC spark, $A C$ arc and DC arc excitations in optical emission spectroscopic systems, the Al metal used in reactors can be characterised for its minor or trace element composition. The best precision of $\pm 6 \%$ is obtained with an $A C$ spark in which the rod sample is taken as a self electrode and elements $\mathrm{Cu}, \mathrm{Fe}, \mathrm{Mn}, \mathrm{Si}$ and $\mathrm{Ti}$ are determined in the concentration range $0.01-1 \%$. The oxide powder sample with DC arcexcitation provides best minimum detection limits of $10 \mathrm{ppm}$ in general and 21 trace elements are determined by it. The $A C$ arc method also uses oxide powder standards prepared synthetically and determines $\mathrm{B}$ and $\mathrm{Mg}$ in addition to the elements determined in AC spark excitation with a precision of $\pm 9 \%$.
\end{abstract}

Keywords. Aluminium; optical emission spectroscopy; excitation sources; precision; elemental characterisation.

\section{Introduction}

Aluminium metal is used in reactors as cladding or calandria material. In the metal so used the high thermal neutron absorbing impurity $B$ should be absent for neutron economy though its presence in the metel is desirable for certain other metallurgical properties. Also the presence of elements $\mathrm{Cu}, \mathrm{Mn}$ and $\mathrm{Ti}$ in minor amounts improves the metal and it gives better castings, can withstand higher lcmperatures and is better suited for machining. Table 1 gives the maximum permissible limits of 14 impurity and/or alloying elements in Al metal used as a ciadding material in thermal reactors. The concentration of these elements varies from 10-4000 ppm. This range can be adequately covered in OES by using AC spark, $A C$ arc and $D C$ arc excitations. For a few elements in relatively high concentrations, like $\mathrm{Fe}, \mathrm{Si}, \mathrm{Cu}, \mathrm{Mn}$ and $\mathrm{Ti}$ an AC spark method (Chandola and Karnik 1971) having a precision of $\pm 6 \%$ is opted for. For the elements present at a low concentration of $10 \mathrm{ppm}$ or so a sensitive method using DC arc excitation (Chandola and Machado 1975) is used. Since the AC spark method uses commercially available rod standards, an alternate method using $\mathrm{AC}$ arc excitation (Chandola et al 1977) is developed in which the synthetically prepared oxide powder standards are used for comparison. Significant features of these methods are described in this paper. 
Table 1. Maximum permissible weights of elements in Al used as cladding naterial in reactors.

\begin{tabular}{lll}
\hline Element & Weight $\%$ & Useful excitation \\
\hline $\mathrm{Co}$ & 0.001 & DC arc \\
$\mathrm{B} \& \mathrm{Cd}$ & 0.002 & DC arc \\
$\mathrm{Cr}, \mathrm{Ni} \& \mathrm{Zn}$ & 0.005 & $\mathrm{DC}$ arc \\
$\mathrm{Cu}, \mathrm{Mn}, \mathrm{Mg} \& \mathrm{Ti}$ & 0.01 & AC spark/AC arc \\
$\mathrm{Ga} \mathrm{\& V}$ & 0.025 & DC arc \\
$\mathrm{Si}$ & 0.2 & AC spark/AC arc \\
$\mathrm{Fe}$ & 0.4 & AC spark/AC arc \\
\hline
\end{tabular}

Table 2. Analytical data for AC spark method.

\begin{tabular}{lccc}
\hline Element & $\begin{array}{c}\text { Analysis line } \\
\AA\end{array}$ & $\begin{array}{c}\text { Estimation } \\
\text { range } \%\end{array}$ & $\begin{array}{c}\text { Standard } \\
\text { deviation } \%\end{array}$ \\
\hline Copper & 3247.5 & $0.006-0.15$ & 7.3 \\
lron & 2600.2 & $0.1-0.76$ & 6.7 \\
Manganese & 2595.8 & $0.007-0.15$ & 3.1 \\
Silicon & 2516.1 & $0.1-0.59$ & 5.3 \\
Titanium & 3349.4 & $0.011-0.06$ & 7.3 \\
Aluminium & 3054.7 & Internal standard & \\
\hline
\end{tabular}

\section{Experimental procedure}

\subsection{AC spark method}

In AC spark method, a $\frac{1}{4}$ inch diameter rod sample is used as lower self electrode against a similar graphite counter electrode. A Eausch and Lomb AC spark unit, with a capacitance in its circuit, provides a $15 \mathrm{kV}$ discharge through a $4 \mathrm{~mm}$ analytical gap between the electrodes. The resulting radiation is dispersed by a large quartz prism in a Hilger spectrograph and the spectrum is recorded in Ilford N. 30 plates, with an exposure time of $90 \mathrm{sec}$, in the wavelength region 2450 $3500 \AA$. It is found by racking plate method that the intensity of analyte elements falls after $90 \mathrm{sec}$, probably due to formation of oxide on the discharge surface; therefore the discharge surface of the sample is filed to expose fresh metal after each exposure. The standards are supplied by Johnson Matthey and Co. under series AA and their composition is given in ASTM Report (Michaelis 1956). The selected lines for analysis, the $\mathrm{Al}$ internal standard line, the determination range and the precision data are given in table 2 . 


\section{2. $D C$ arc method}

For the DC arc method, the metal is converted to oxide by dissolution in $\mathrm{HCl}$, precipitation with $\mathrm{NH}_{4} \mathrm{OH}$, drying the precipitate and supernatant solution

Table 3. Analytical data for DC arc method

\begin{tabular}{|c|c|c|c|}
\hline Element & $\begin{array}{c}\text { Analytical } \\
\text { line } \\
\AA\end{array}$ & $\begin{array}{c}\text { Estimation } \\
\text { range } \\
\text { ppm }\end{array}$ & $\begin{array}{c}\text { Standard } \\
\text { deviation }+ \\
\%\end{array}$ \\
\hline Antimony & 2598.1 & $10-1000$ & 7 \\
\hline Bismuth* & 3067.7 & $5-500$ & - \\
\hline Boron & 2497.7 & $10-200$ & - \\
\hline Cobalt & 2424.9 & $10-1000$ & 18 \\
\hline Cadmium & $3261 \cdot 1$ & $20-500$ & 5 \\
\hline Copper* & 3274.0 & $5-200$ & 22 \\
\hline Chromium & $2835 \cdot 6$ & $5-1000$ & 7 \\
\hline Gallium & $2944 \cdot 2$ & $8-50$ & 15 \\
\hline Indium** & 3256.0 & $10-500$ & - \\
\hline Iron & 2599.4 & $13-1000$ & 7 \\
\hline Lead & $2833 \cdot 1$ & $5-100$ & 14 \\
\hline Magnesium & 2779.8 & $10-200$ & 21 \\
\hline Manganese & 2605.7 & $5-100$ & 7 \\
\hline Molybdenum & $3170 \cdot 3$ & $10-500$ & - \\
\hline Nickel & .3050 .8 & $10-200$ & 7 \\
\hline Silicon & 2435.2 & $70-1000$ & - \\
\hline Silver* & 3280.7 & $5-500$ & 7 \\
\hline $\operatorname{Tin} * *$ & $2840 \cdot 0$ & $10-500$ & - \\
\hline Titanium & 3199.9 & $10-1000$ & 12 \\
\hline Vanadium & $3183 \ldots$ & $10-200$ & 15 \\
\hline Zinc & $3282 \cdot 3$ & $100-1000$ & - \\
\hline Aluminium & 2669.2 & Internal standard & \\
\hline
\end{tabular}

* Measured in 10\% transmission step

From 11 deteminations for 50 ppn standard

*: Only visual estimate is done

together and ignition. The alumina so obtained is mixed with pure graphite powder spectroscopic buffer in the weight ratio 1:1. Standards are prepared on pure allimia (Johnson Matthey and Company) by dry-mixing the Spex-Mix powder containing 49 elements and subsequent dilutions. The standards are also mixed with buffer similar to samples. A charge of $20 \mathrm{mg}$ of sample-graphite mixture is placed in the cavity of $\frac{1}{4}$ inch diameter graphite electrode. A $\frac{1}{5}$ inch diameter graphite rod pointed at one end serves as a counter electrode and the analytical gap is kept at $4 \mathrm{~mm}$. A DC arc at a current of $10 \mathrm{~A}$ is passed in the analytical gap making the sample electrode an anode. The resulting radiation is disperse 1 and photographed similar to AC spark method. A neutral filter giving $100 \%$ and $10 \%$ transmission steps is placed in front of the slit for the determination of $\mathrm{Ag}$ and $\mathrm{Cu}$ which fall in the high background region of the spectrum. The 21 elements analysed by this method and other analytical data are given in table 3 . 


\subsection{AC arc method}

The $\mathrm{AC}$ arc method also takes oxide powder as sample, $10 \mathrm{mg}$ of which is stuck to a pair of flat topped $\frac{1}{4}$ inch diameter graphite electrodes with the help of a sticking cement-like Stickfast or radio TV service cement. Standards containing B, $\mathrm{Cu}, \mathrm{Fe}, \mathrm{Mg}, \mathrm{Mn}$, Si and $\mathrm{Ti}$ are prepared by dry-mixing the appropriate amounts of compounds of these elements to alumina. The sample is excited by an AC arc source (JACO Custom Varisource) and the resulting radiation is dispersed by a 15,000 lines per inch grating and photographed on Kodak SA-1 plates giving an exposure time of $60 \mathrm{sec}$. A neutral filter giving 100\% and 18\% transmission is placed in front of the slit to cover the required concentration range. The analytical data are given in table 4.

\section{Results and discussion}

The working curves relating log concentration with log intensity ratio are found to be linear in the concentration ranges given in tables 2,3 and 4 . The precision in terms of percent standard deviation is also given in these tables and is averaged as $\pm 6 \%$ for $\mathrm{AC}$ spark, $\pm 12 \%$ for $\mathrm{DC}$ arc and $\pm 9 \%$ for $\mathrm{AC}$ arc.

Accuracy was tested for $\mathrm{Cu}, \mathrm{Fe}, \mathrm{Mn}$ and $\mathrm{Si}$ by $\mathrm{DC}$ arc method by analysing some AA series standards after their conversion to oxide. The accuracy was found to be good and it was shown that for these elements there is no loss during conversion of metal to oxide by the procedure adopted. A separate set of experiments showed that there is no loss of element $B$ during the conversion thus making the method useful for reactor technology application.

\section{Conclusions}

Three simple procedures described in this paper enable the complete elemental characterisation of the reactor cladding $\mathrm{Al}$. These procedures are routinely in

Table 4. Analytical data for $\mathrm{AC}$ arc method.

\begin{tabular}{|c|c|c|c|}
\hline Element & $\begin{array}{c}\text { Wavelength } \\
\AA\end{array}$ & $\begin{array}{c}\text { Concentration } \\
\text { range \% }\end{array}$ & $\begin{array}{r}\text { Standard } \\
\text { deviation \% } \\
\end{array}$ \\
\hline Boron & 2497.7 & $0.025-0.1$ & 4 \\
\hline Boron* & ,, & $0.1-1$ & - \\
\hline Copper* & 3247.5 & $0.025-0.25$ & 17 \\
\hline Iron* & 2599.6 & $0.05-1$ & 7 \\
\hline Magnesium & $2779 \cdot 8$ & $0.025 \cdot 0.1$ & 12 \\
\hline Magnesium* &, & $0.25-1$ & - \\
\hline Manganese & 2605.7 & $0.025-1$ & 6 \\
\hline Manganese* & , & $0.1-1$ & - \\
\hline Silicon* & $2514 \cdot 3$ & $0.1-1$ & 7 \\
\hline Titanium & 3234.5 & $0.025-0.25$ & 8 \\
\hline Titanium* & & $0.1-1$ & - \\
\hline Aluminium & 2652.5 & Internal sta & \\
\hline
\end{tabular}

*Measured in $18 \%$ transmittance step. 
use at the Spectroscopy Laboratories of BARC, Bombay and have solved many problems which arise during the construction and operation of reactors at this Centre.

\section{Acknowledgements}

The author expresses his gratitude to $\operatorname{Dr} \mathrm{N}$ A Narasimham, Spectroscopy Group for his interest in this work and constant encouragement. Thanks are due to the authorities of Instituto de Energia Atomica, Sao Paulo (Brazil) where a part of this work was done during the author's stay there as an international collaborator. Thanks are also due to all the associates in India and Brazll who helped in this work.

\section{References}

Chandola L C, Brito J De, Gomes R P and Lordello A R 1977 Spectrographic analysis of AI for minor alloying and impurity elements employing an AC are excitation. Instituto de Energia Atomica (Brazil) Report IEA-499

Chandola L C and Karnik P D 1971 Spectrographic estimation of impurities in Al metal Atomic Energy Commission (India) Report BARC-1/111

Chandola $\mathrm{L} C$ and Machado I J 1975 Indian J. Technol. 13471

Michaelis R E 1955(Compiler)ASTM Report on Standard samples and related materials for spectrochemical analysis ASTM Philadelphia 28 